原 著

\title{
リンパ節造影および放射線照射後の骨盤内 リンパ節の細胞像について
}

\author{
岩手県立成人病センター婦人科 \\ 木林 瑛飯田 肇 \\ 岩手医科大学医学部産婦人科学教室 \\ 利部輝雄
}

はじめに

リンパ節の穿刺標本を細胞学的に検討し，疾患の診断 にはじめて応用したのは Ward $(1914)^{1,2)}$ であり，本邦 では森 $(1943)^{3)}$ である．以来細胞診の分野では穿刺塗 抹細胞診について数多くの業績が発表されており，悪性 腫晹の術中組織診，細胞診はその手術方針の決定に重要 である.また，リンパ節転移の診断にさいして摘出リン パ節捺印細胞診の正診率は高く, 多くの人々により応用 されている ${ }^{3 \sim 5,7)}$ ，子宮頸癌手術のさいのリンパ節転移 に関しては，西村5) が術中捺印細胞診について詳細な報 告をしている。しかしリンパ節造影の影響や放射線によ る変化についての報告沙ない。このたび，われわれは リンパ節造影や放射線照射後の術中リンパ節拪印標本の 細胞像について検討したので報告する.

\section{研究対象および方法}

岩手県立成人病センター婦人科および岩手医科大学医 学部産婦人科学教室にて子宮頸癌と診断された患者 (18 例，病理組織学的には扁平上皮癌）を表 1 のごとき各群 に分けた。これらについて広範性子宮全摘術または腹膜 外リンパ節廓清術を行い，摘出した骨盤内リンパ節の割 面から捺印標本を作製した．捺印標本の固定はエーテ ル，95\% エチルアルコール等量混合液で，パパニコロ ウ染色は EA 50 で行った.

Imprint Smear Cytology of Pelvic Lymph Nodes after Lymphography and X-ray Irradiation

Akira KIBAYASHI, M.D., Hajime IIDA, M.D.

Dept. of Gynecology Iwate Center for adult disease

Teruo KAGABU, M.D., M.I.A.C.

Dept. of Obstetrics and Gynecology Iwate Medical

University

昭和 49 年 5 月 24 日受付
照射は $10 \mathrm{MV}$ ライナック $\mathrm{X}$ 線による照射野 $15 \times 15$ $\mathrm{cm}$ の全骨盤内照射で，原発巣および骨盤内リンパ節へ の線量は 1 回 $250 \mathrm{rad}$ とした.リンパ節造影は両足背の リンパ管より造影剤を注入する Kinmonth 法により行 った、リンパ節造影や放射線治療と手術までの期閒は表 1 のごとくである.

捺印標本中のリンパ球，細網細胞，多核細胞，形質細 胞および癌細胞についてそれぞれ核直径 (長径), 細胞 質直径（長径）を計測しその分布図を作製した。多核細 胞の核の直径はそれぞれの核の長径の平均值で示した。 検索した標本は 335, 計測した細胞数は 30750 である.

\section{細胞学的所見と分布域}

1.リンパ球（図 1〜10)

正常リンパ節におけるリンパ球の大きさは $8.8 \pm 2.8$

表 1
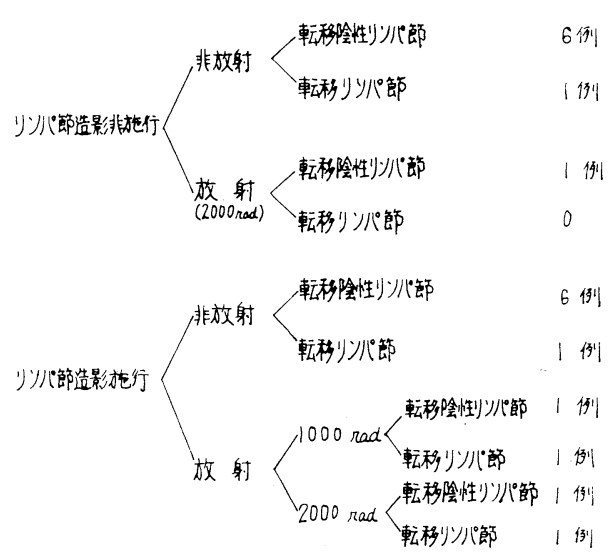

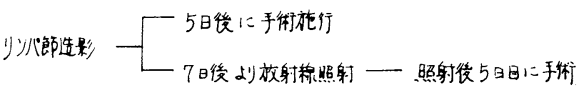


$\mu$, 細胞質は弱好ライトグリーン性で, 小型のものでは 細胞質が狭少となり裸核に近いものもみられる.大リン パ球の細胞質は比較的豊富で核周囲に明庭がみられる. 核の大きさは $6.7 \pm 2.2 \mu$, 円形あるいは棈円形でク口 マチンは粗剛, 核小体は 1 ～個認められる. 転移リン パ節におけるリンパ球の大きさは対照と差がないが，そ のばらつきは大きくなる傾向がみられる.リンパ節造影 によるリンパ球の分布への影響は少なく，大きさ，ばら つきも対照と差がない。放射線照射をうけたリンパ節の リンパ球は一般に小さくなる傾向があり，特に転移のな いリンパ節のリンパ球の大きさは有意 $(t=3.41)$ にさ く，その分布の幅もせまくなる.しかし核の大きさには 著変はない.リンパ球の核の構造にはリンパ節転移，リ ンパ節造影, 放射線照射などによると思われる明らかな 変化は見出せなかった.

\section{2. 細網細胞（図 1 9, 11, 写真 1)}

正常リンパ節における細網細胞の出現頻度は約 $5 \%$ で あり，大きさ(細胞の長径) は $25.2 \pm 4.7 \mu$ ある. 大多数の細胞は細胞質が弱好ライトグリーン性で淡染傾 向を示し, 時に網状構造がみられ, 辺縁は不整, 不明瞭 である. 核は楕円形のものが多く, その大きさ（核の長 径) は $11.3 \pm 1.7 \mu$ で, 繊細な核網像を有し, 核小体は $1 \sim 3$ 個で中等大円形のものが多い. 転移のみられるリ ンパ節では細網細胞の大きさは非転移リンパ節に比べて 小さくなる傾向がみられるが，核の大きさには差がな い.また細胞や核の大きさのばらつきにも差がみられな い. 細網細胞の細胞質や核の構造にも大きな差はみられ ないが，少数ながら食作用がないとされている好エオジ ン性の細胞質をもつ細網細胞がみられた. リンパ節造影 を行ったリンパ節の細網細胞の大きさの分布は対照と差 があり, $18 \mu$ と $26 \mu$ の 2 つのピークをもつ分布曲線で 示される. しかし核の大きさの分布には差がみられな い.これらの細網細胞の細胞質はその辺縁が明瞭でまる みを帯びており，一般に好ライトグリーン性がつよい が，ごく少数の細胞では核の周囲が好エオジン性または ライトグリーンに淡染するものもみられる. 細胞質内の 網状構造は繊細で，これは大きな細網細胞ほど著明であ る。また核は楕円形で核小体は明瞭なものが多く，核は 一般にあかるく，クロマチンは細〜粗顆粒状である. 放 射線照射による細網細胞の大きさの変化は著明でなく, 細胞質の好ライトグリーン性は一般に強く, 網状構造は ほとんどみられなくなり, 辺縁は比較的整でまるみをお びている．核の大きさは $1000 \mathrm{rad}$ 照射では非照射例と 差はないが， $2000 \mathrm{rad}$ 照射では有意 $(t=5.59)$ に小さ くなる、核形は棈円形でクロコチンは粗網状を呈し，核
縁肥厚, 核小体の腫大をみとめる. また細胞質の空胞形 成 (1000 rad) もみられる。

\section{3. 形質細胞（図 1９， 12, 写真 1)}

正常リンパ節の捺印標本にあらわれる形質細胞は直径 $11.3 \pm 5.2 \mu$, 細胞質は核に比し豊富で，好ライトグリ ーン性が強く, 細胞の形は棈円形のものが多く, 辺縁は 整である。核は円形, クロマチンは粗剛, 特有な車軸状 分布を示し，偏在した核と核側明庭を示すものが多い. 転移リンパ節や造影リンパ節の捺印標本中の形質細胞に は，大きさやばらつきに詨照との差はみとめられない. また放射線照射による変化も著明ではなかった。しか し，リンパ節造影を行い $2000 \mathrm{rad}$ 照射した転移陽性の リンパ節では細胞の大きさが $16.8 \pm 3.8 \mu$, 核の大きさ が $8.9 \pm 2.0 \mu$, と他の場合に比べて有意 $(t=9.08)$ に 大きく，そのばらつきも有意 $(F=2.73)$ に大きかった.

\section{4. 多核組織球 (図 1 9, 13, 写真 1)}

造影リンパ節の捺印標本中の多核組織球は大きさ（長 径) $30 \sim 250 \mu$ (平均 $76.2 \pm 41.3 \mu$ ) の円形または棈円 形で, 細胞の辺縁は整, $10.3 \pm 1.8 \mu$ の核を 2 ～数 10 個 もっている. 細胞質は好ライトグリーン性, 時に中心部 に好エオジン性で淡染し，小泡抹状である。核は円形〜 棈円形で偏在性を示し, クロマチンは微細顆粒状で，核 小体は不明瞭なことが多い、転移陽性リンパ節の多核組 織球は転移陰性のリンパ節のそれと大きさ，核数，染色 性に差はない。しかし，放射線照射をうけた場合転移の 有無にかかわらず，多核組織球は線量の増加とともにそ の長径は有意 $(t=5.75)$ に短縮し, 細胞質の好ライトグ リーン性が強度となる。核の大きさには著変がないが, 核縁の肥厚がみとめられ，クロマチンは粗大顆粒状とな り，少数に核小体の大型化がみられる．2000 rad 照射の ばあい，多核組織球は小型化し，細胞の形が円形に変る ものが多い.

\section{5. 癌細胞 (図 2,4,6, 9, 写真 2,3)}

腟スミアにおける悪性細胞の診断基準は, 核ではその 大きさの大小不同および不整形, 核・細胞質比の増大, クロマチン量の増加による過染性, 粗大顆粒状凝集, 核 縁の肥厚不整, 著明な核小体の出現, 核分裂像および多 核等である.また，ときにクロマチンが淡染性となり， 核の辺縁や核内の諸所に集積することがある・細胞質 は，核に比べて少なくなり，形がふぞろいで，辺縁不 整, 空胞形成, 染色性の変化がみられる.

リンパ節の捺印標本中では転移覀性細胞が集団をなし て現われる事が多いようである. 悪性細胞が散在性に現 われる場合, 細胞質がライトグリーンで染色されるよう な細胞では, 大きさ $25 \sim 30 \mu$, 細胞の辺縁不整, 境界 
明瞭，細胞質の構造は微細網状で，核は大きさ $10 \sim 17$ $\mu$, 不整形クロマチンは粗大顆粒状に凝集している. 細 胞質がオレンジ好性を示す細胞では，大きさ $21 〜 40 \mu$, 細胞境界は明瞭で, 榜は 3〜 $5 \mu$, 核形不整でクロマチ ンは粗大顆粒状に凝集している。転移陽性リンパ節に放 射線 $1000 \mathrm{rad}$ 照射した場合, 癌細胞の変化は, 裸核の 出現, 核の膨大と過染性, 濃縮と崩壊, 空胞形成, 多 核, 細胞質の空胞形成等であった. $2000 \mathrm{rad}$ 照射では悪 性細胞の細胞質全体が “もや”がかかったような外観を 呈し, 細胞質は粗な網状構造となり淡く，核はほとんど 核網構造を失い, 核融解や無核細胞がみられた。また核 小体の腫大もみとめられた。 これらの所見は，そのさい の腟スミアにおける所見と同様であった。

\section{考案}

リンパ節は皮質と髄質に大別され，皮質を構成するも のは主としてリンパ球で, リンパ洞を中心に細網細胞, 洞内皮細胞, 形質細胞, 組織肥㭌細胞等が髄質を構成す る $^{8 \sim 12,21,24)}$.

リンパ節造影を行った場合の変化は主にリンパ節の髄 質を構成する細胞の形態上の変化と数的な増減として現 われる.その組織像は, 著明なリンパ濾胞の増生, 被膜 および周縁リンパ洞および皮質の線維化，リンパ洞内皮 (細網細胞) の増生腫大, 単球, 形質細胞の出現, リン パ洞内の組織球性細胞の出現 ${ }^{13}$ 16), 洞細網内皮の増殖 である ${ }^{20)}$. 捺印標本ではリンパ球, 形質細胞ともに著変 はみられないが, 細網細胞の直径の分布に 2 つのヒーク がありこれは刺激型細網細胞の出現と考えられた. たリンパ節造影に対する反応とみられる組織球性の細胞 の出現がみられ，その大きさは 30〜 $250 \mu$ (平均 76.2土 $41.3 \mu)$, 核は $10.3 \pm 1.8 \mu$ の円形または棈円形で, 2 〜数十個の核を有している (多核). 細胞質の染色性は 好ライトグリーン性である.

転移陽性リンパ節の組織像では20), 転移が被膜のリン パ管内にのみ限局する場合, リンパ滤胞の反応性増殖が みられることがあるといわれ，浸潤がリンパ洞内におよ ぶとリンパ小節の消失, 腫大した細網細胞の増生, 好酸 球の出現, 形質細胞の浸潤, 線維芽細胞の増生がみら れ，転移がリンパ節全体におよごときでも正常リンパ組 織の残存が多少ともみられることがあるといわれてい る. 捺印標本ではリンパ球, 形質細胞には著変がみられ ず，細網細胞は一般に小さくなる傾向がみられたが，細 胞や核の大きさのばらつきは非転移リンパ節のそれと差 はみられなかった。

放射線照射をうけたリンパ節の組織像は ${ }^{17 \sim 19)}$, リンパ
濾胞の破壊, 核崩壊物質の濾胞内一の出現, 濾胞の鬆粗 化, 滤胞周囲における細胞質の濃染した細網細胞と多核 組織球の出現等である. 放射線量の増加にともないその 傾向は強く, リンパ球の核濃縮および崩壊, 細網細胞で は細胞質の濃染および狭少化, 形質細胞の減少や多核組 織球の小型化などがみられた。転移陽性リンパ節におけ る癌細胞の放射線による変化は, 原発巣のそれと変りな く, $1000 \mathrm{rad}$ では細胞の腫大, 核内空胞の形成, クロマ チンの粗大凝集, 核小体の腫大と染色性の変化, 裸核細 胞の出現等, $2000 \mathrm{rad}$ では巣状壊死，核の染色性の低 下，核濃縮細胞の出現などがある. 捺印標本ではリンパ 球には著変はみとめられないが, 細網細胞では核の大き さが放射線量の増加により小さくなる傾向がみられ，形 質細胞はリンパ節造影後 $2000 \mathrm{rad}$ 照射したリンパ節で は細胞，核ともにその大きさおよびばらつきが大であっ た. 多核組織球は線量の増加とともに細胞の直径は小さ くなる傾向がみられたが，核の大きさには変化がなかっ た. 癌細胞は腟スミアの癌細胞の放射線照射による変化 と同様の所見を呈した.

リンパ節本来の細胞の放射線照射による変化が少なか ったのは, 照射線量, 照射から摘出までの期間における 回復などの問題が考えられ, 今後の検討が必要であろ う。また転移陽性リンパ節の $2000 \mathrm{rad}$ 照射による形 質細胞の変化は, 照射された癌とリンパ節の lmmune mechanism を示唆するものと考えられる.

\section{結語}

リンパ節造影や放射線照射後の術中リンパ節掩印標本 の細胞像について検討し，次の結果を得た。

1.リンパ節造影の影響

a . 細網細胞の大きさの分布に 2 峰性がみられ, 腫大 傾向がうかがわれる。

b. 多核組織球の出現,

2. 放射線照射による変化

a 、細網細胞には放射線による影響は少ないが，2000 $\operatorname{rad}$ 照射で核が小さくなる傾向がみられた。

b. 多核組織球は放射線照射により小さくなる.

c . 形質細胞は $2000 \mathrm{rad}$ 照射時 (リンパ節造影が行 なわれ，転移陽性のばあい）に細胞，核の腫大，大 きさのばらつきの拉大がみられた。

$\mathrm{d}$. 扁平上皮癌細胞 (転移) は，典型的な放射線変化 を示すものが多い.

稿を終るに臨み，ご指導，ご校閲を賜った岩手医科大学医学 部産婦人科学教室秦良麿教授に深甚なる謝意を表します. 
なおこの論文は第 15 回日本臨床細胞学会総会で発表しまし た.

\section{Summury}

The following observations were made by imprint smear cytology of pelvic lymph nodes in patient with cervical cancer after lymphography and irradiation.

1. Influences of lymphography

a) As regards size distribution of retictlum cells, a bimodial distribution was observed. A tendency to enlargement of reticulum cells was also observed.

b) Appearance of multinuclear histiocytes.

2. Cytological changes due to Linac X-ray irradiation

a) Nuclei of reticulum cells decreased in size after 2,000 rad of Linac X-ray irradiation.

b) Decrease in cell size was seen in multinuclear histiocytes.

c) Enlargement and wide variation of the size of cells and nuclei were observed in plasma cells after 2,000 rad of radiation (in those cases lymphography was performed and positive metastasis revealed).

d) Many of metastatic squamous cell carcinoma cells showed the typical radiation changes.

\section{文献}

1) Ward, G.R. : (Stahel )

2) Stahel, R. : Diagnostische Drüsenpunktion. Georg Thieme, Leipzig, 1939.

3）森 英章：淋巴節穿刺，日血会誌， 7:1, 1943.

4) Lucas, P.F. : Diagnostic value of lymph node aspiration biopsy. Postgrad. M.J. 30 : 544, 1954.

5）西村敏雄, 吉田吉信, 中村 豊: 転移の術中診断, 産婦 治療, $19: 276 ; 1969$.

6）小島 秋, 他 7 名 : 子宮頸癌のリンパ節転移の診断, ンパ管造影法, リンパ節捺印法の比較検討, 産婦治療,
$21: 557,1970$.

7）林田健男, 他 7 名：術中細胞診, 日本臨床, $24: 1869$,, 1966.

8）小野三郎：脿器穿刺C，淋巴節，日本血液学全書， 6 ： 395, 1964.

9）小野三郎，八井田一郎：淋巴節穿刺, 血液学討議会報 告, VI, 153, 1954 .

10）海野源太郎, 花岡正男：淋巴球の発生, 血液学討議会報 告, $\mathrm{VI}, 62,1954$.

11）堀内 篤: リンパ節腫脹の細胞学的研究, 綜合医学, 17 : 637, 1960.

12）八井田一男, 小野三郎, 森 栄吉 : 淋巴腺腫煌とその臨 床細胞学的検討, 癌の臨床, $2: 9,1956$.

13）赤崎兼義，小島 瑞：炎症栄に於ける網内系細胞の態 度, 血液学討議会報告, VII, 121，1954.

14）赤崎兼義：細網内皮系統とその病理，日病理会誌，41： $1,1952$.

15）生田輝喜：炎症巣に於ける各種巨細胞の発生に関する研 究, 日血会誌, $13: 1,1950$.

16）赤崎兼義：細網内皮系統とその病理，日医新報，1698， 3, 1956.

17）増淵一正：悪性腫瘍/淋巴腺転移二就テ, 日婦会誌， 37 $: 1224,1942$.

18) Rubin, P. \& Casarett, G.W. : Clinical Radiation Pathology. Vol. II, 825, 1968.

19) Scherer, E. und Stender, H-S.:Strahlenpathologie der Zelle. Georg Thieme, Stuttgart, 164, 1963.

20) Robbins, S.L. : Textbook of pathology with clinical application. 509, 1962.

21）城所 働, 他 : 悪性腫瘍転移リンパ節の臨床細胞学的検 討, 日臨細胞会誌, $5: 145,966$.

22) Fuchs, W.A. \& Böök-Hederström, G. : Lymphography in the diagnosis of metastasis with special reference to the carcinoma of the uterine cervix. Acta Radiol. 2 : 161, 1964.

23）吉田吉信：子宮頸癌骨盤リンパ節転移のImprint法につ いて, 産婦の進歩, $19:$ 338, 1967.

24）小野三郎, 加藤年克・リンパ節細胞診, 日本臨床, 24 : 1910.

25) 小島 瑞, 斉藤武郎：細網内皮症, 最新医学, $17: 1054$, 1962. 


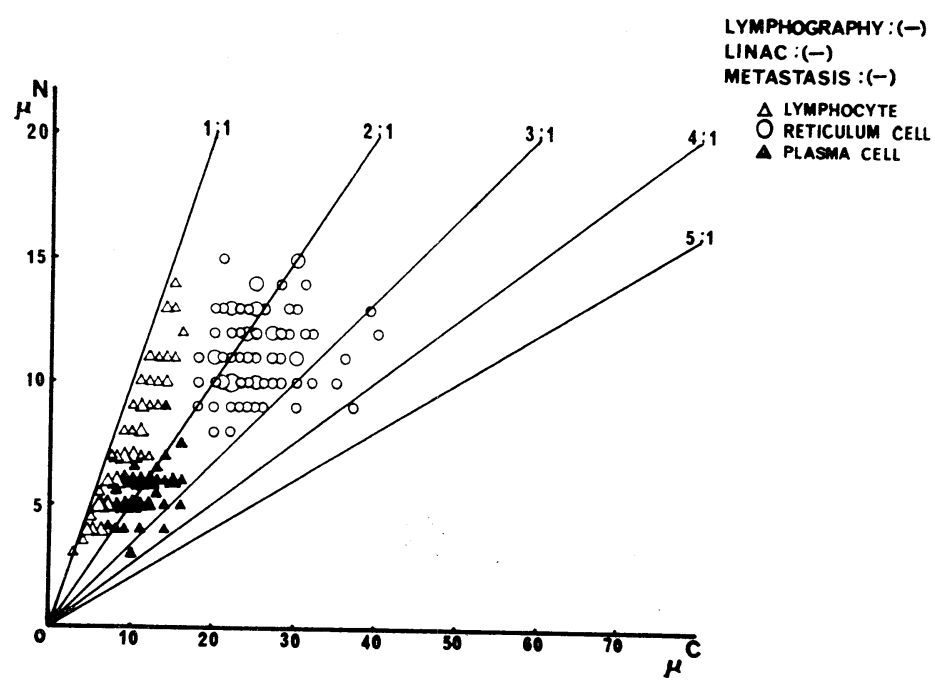

図 1
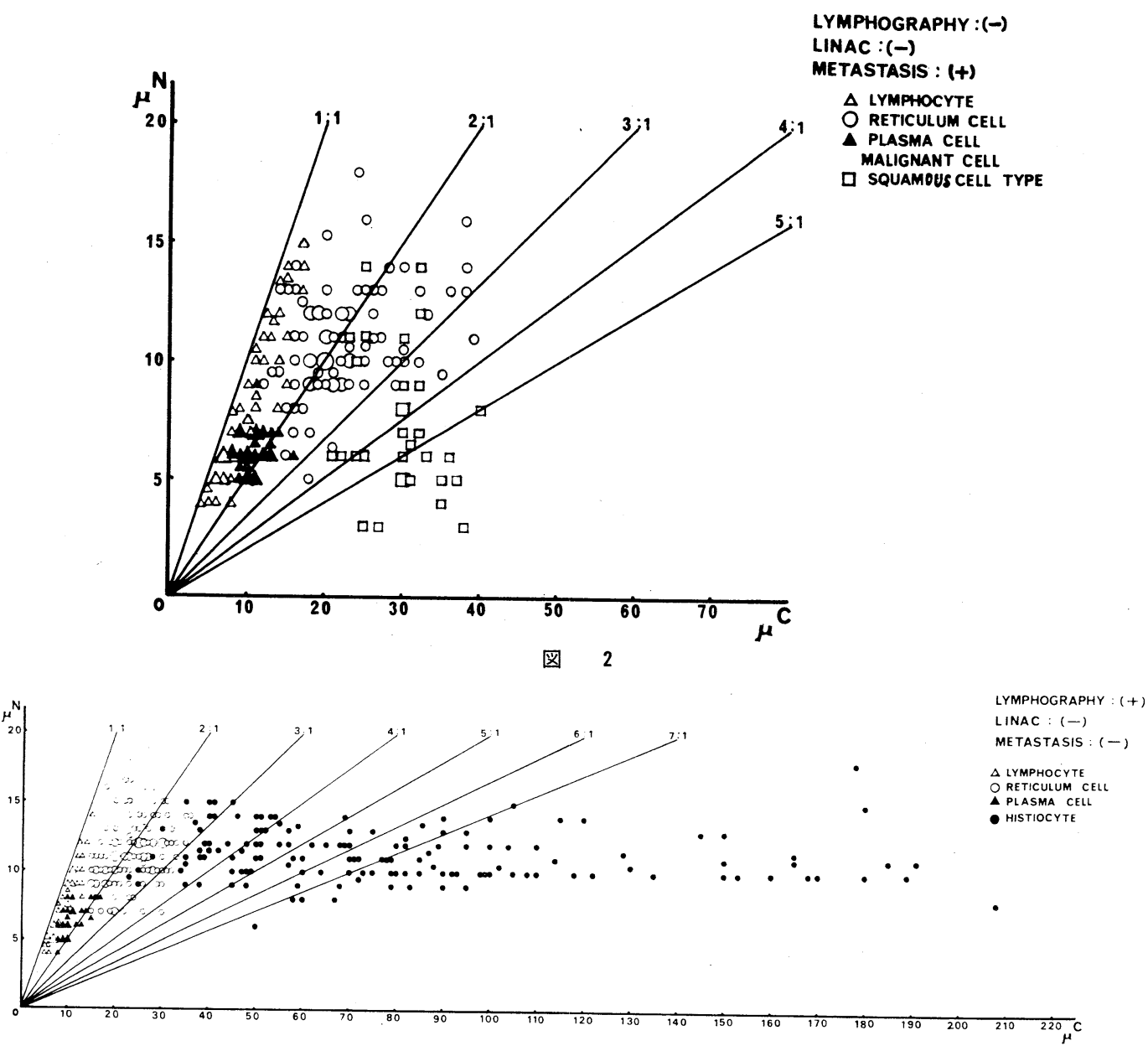

図 13 


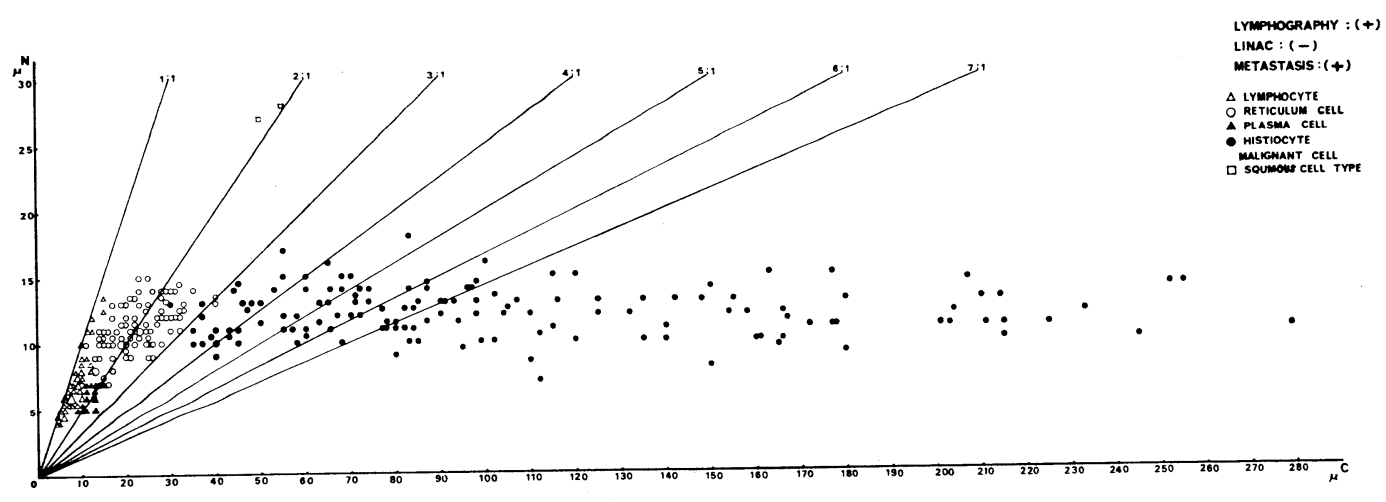

図 4

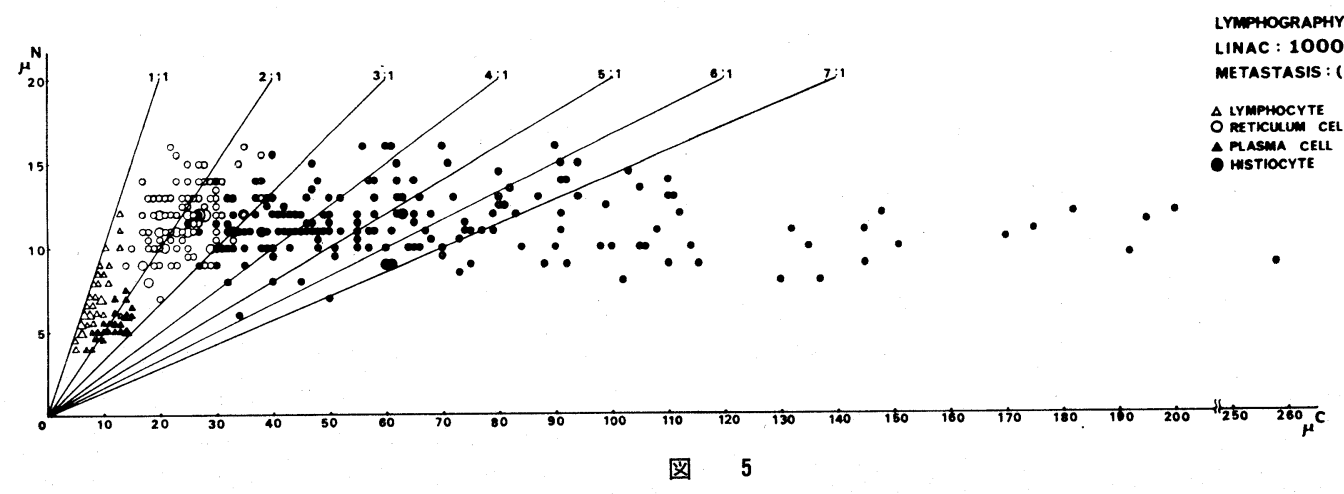

LYMPHOGRAPHY : (+) LINAC: 1000 RAD METASTASIS: $(+)$

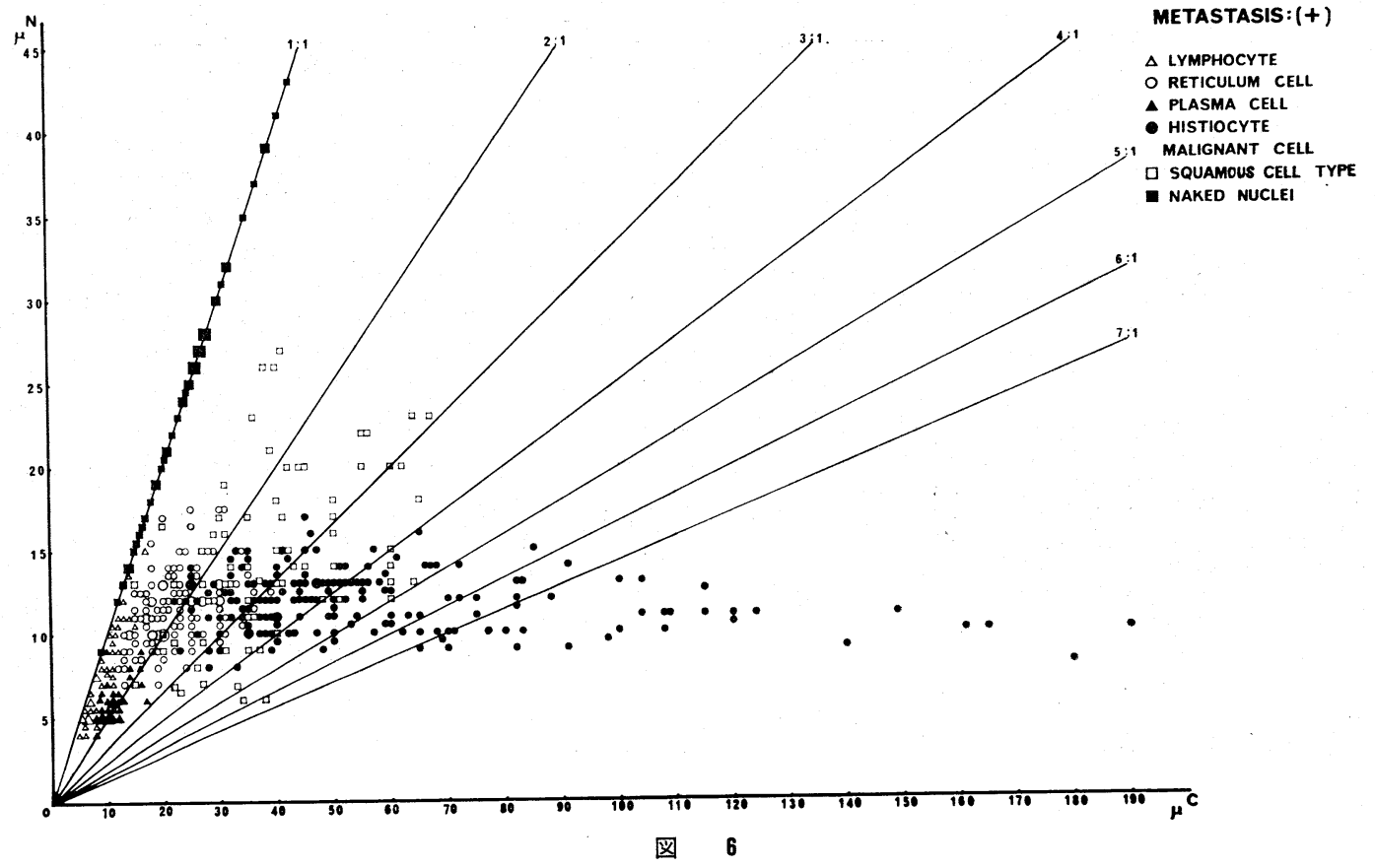



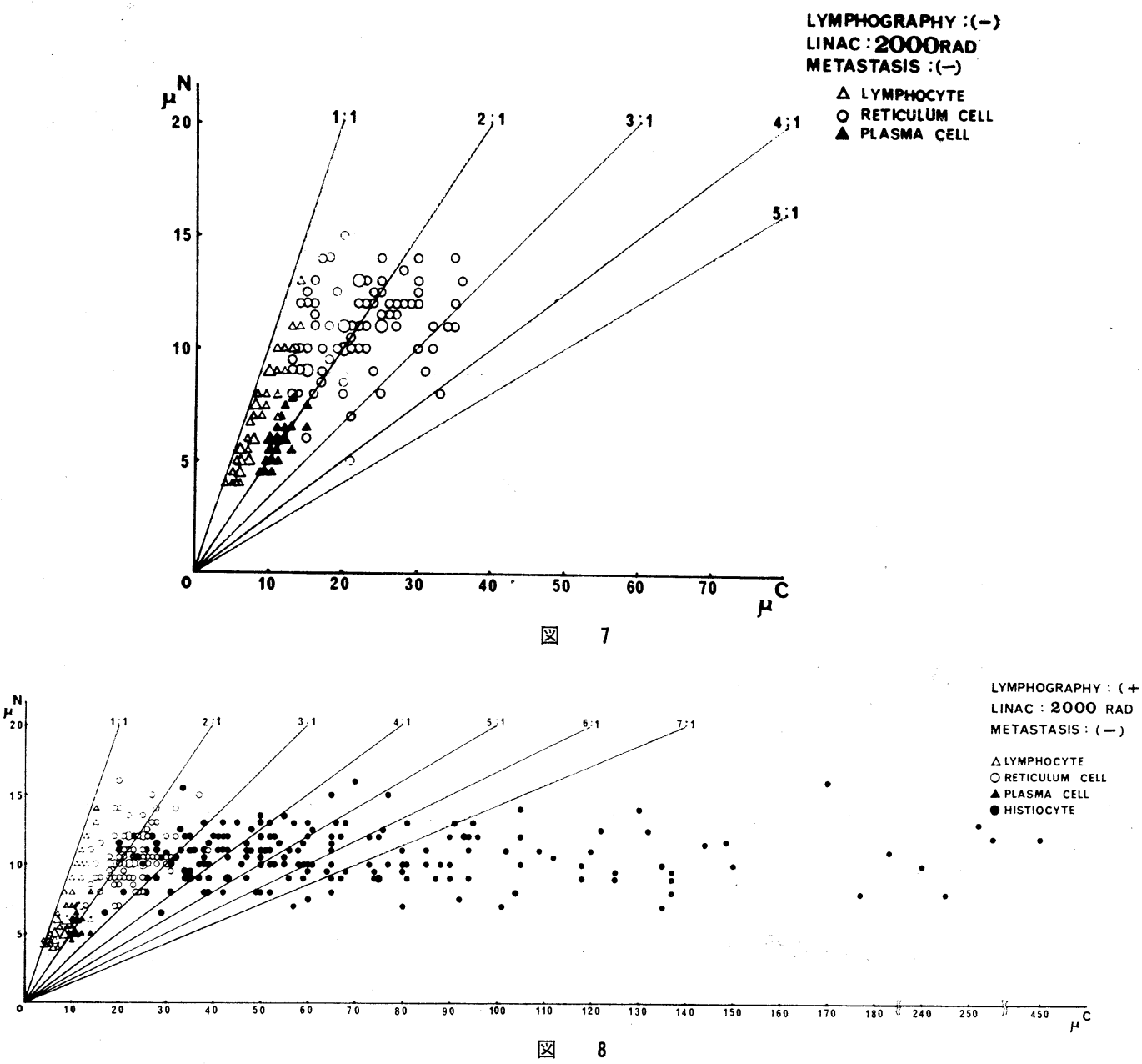

LYMPHOGRAPHY : (+) LINAC : 2000 RAD METASTASIS : (+)

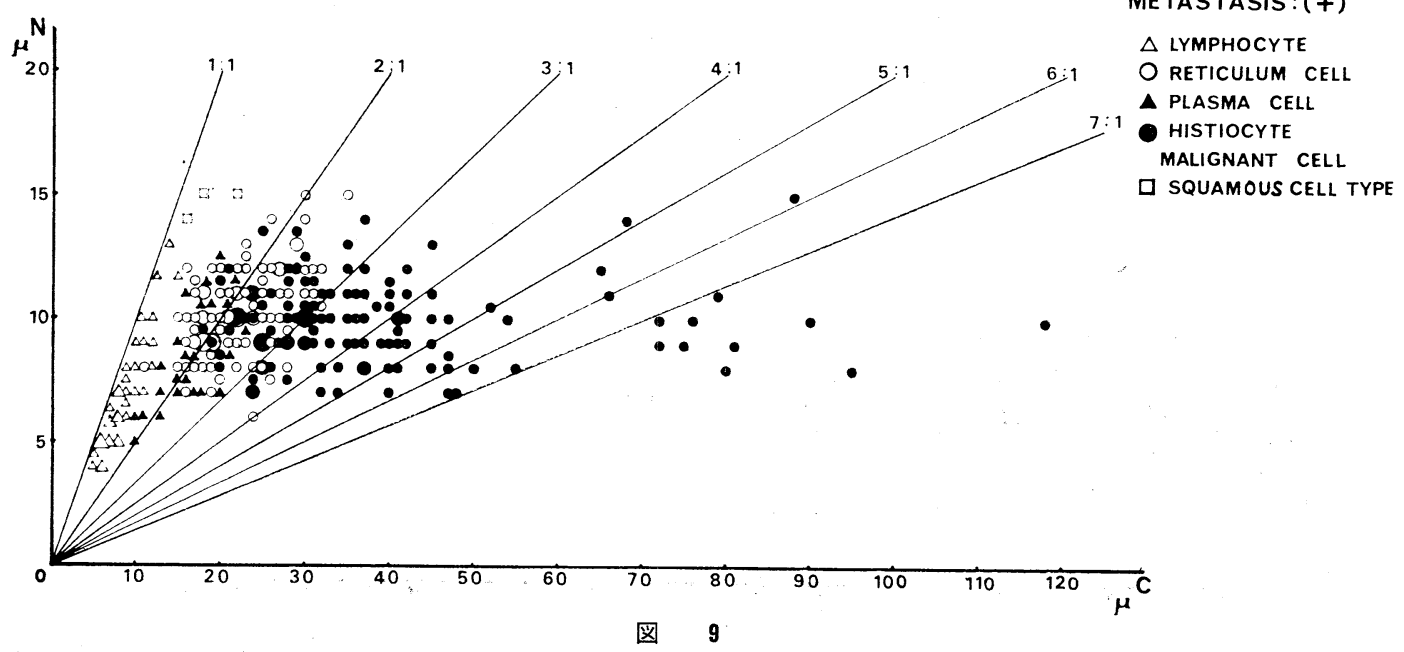



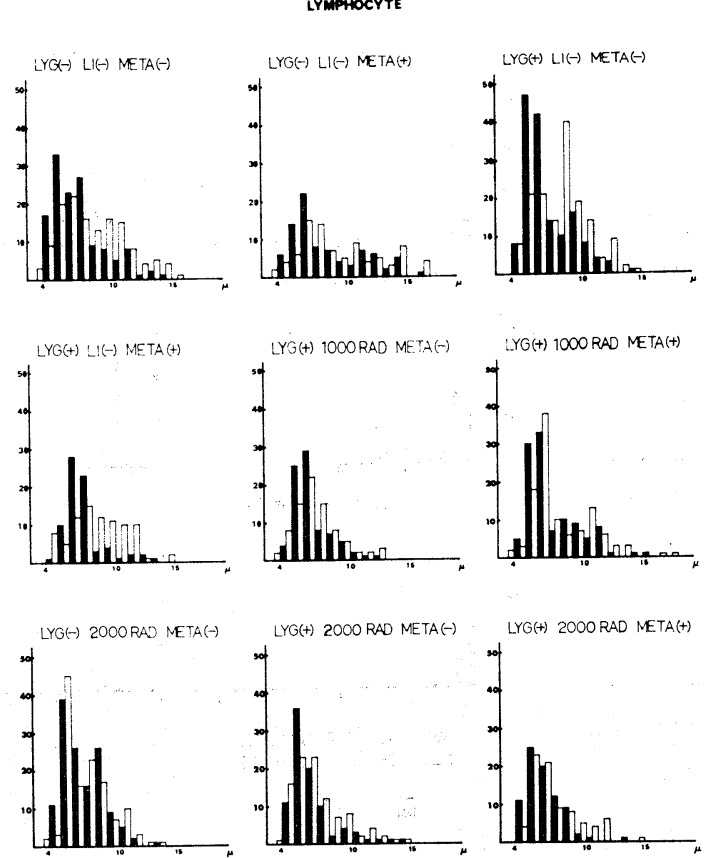

LYG : LYMPHOGRAPHY

LI: LINAC

META: METASTASIS

$\Xi$ NUCLEAR DIAMETER

図 10

RETICULUM CELL
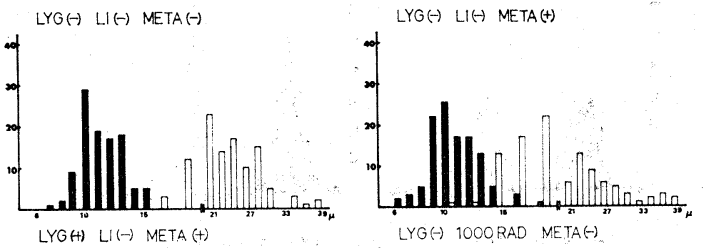

LYG $(+)$ LI $\leftrightarrow$ META $(-)$
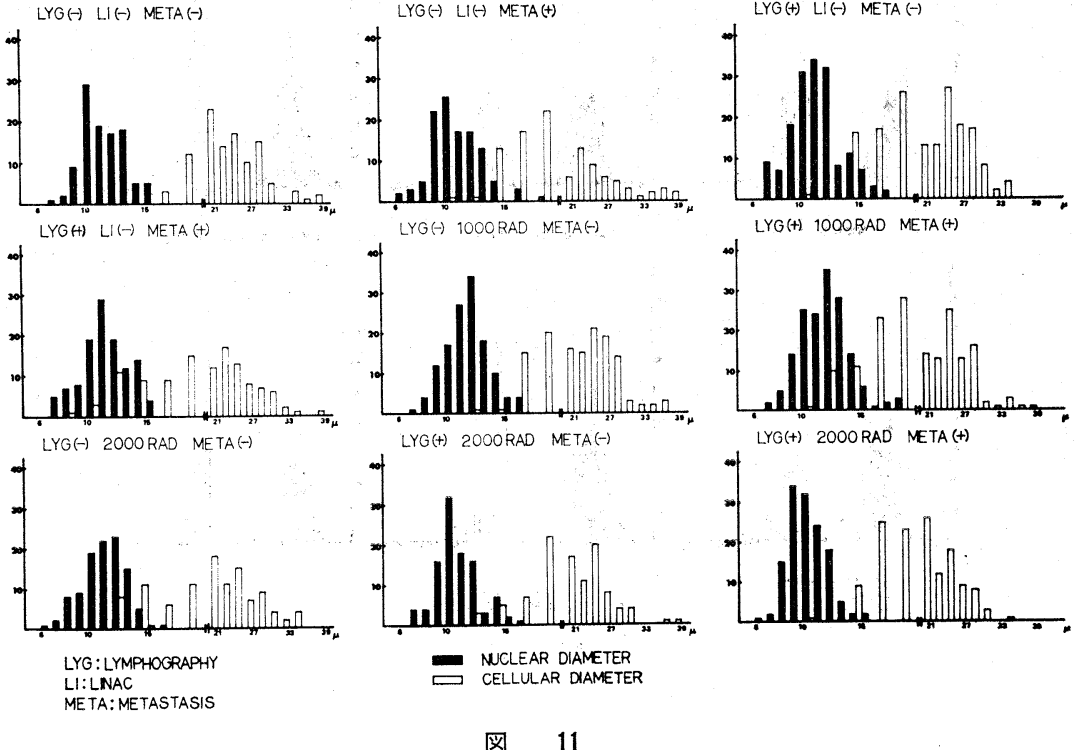

図 11 
PLASMA CELL
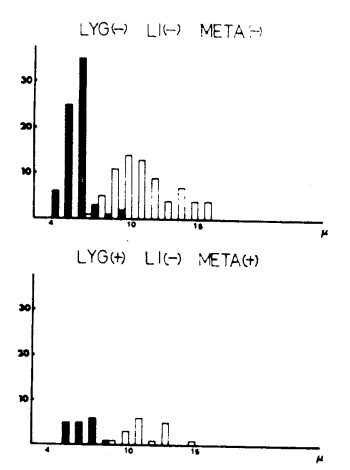

LYG $(-)$ 2000RAD META( -$)$

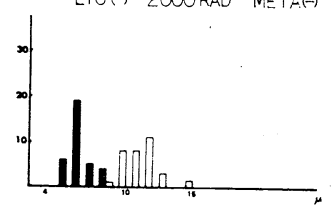

LYG: LYMPHOGRAPHY LI LINAC

META METASTASIS
LYG $\rightarrow$ LI $(-)$ META(t)

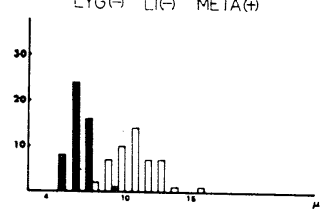

LYG(t) 1000RAD META $(-)$

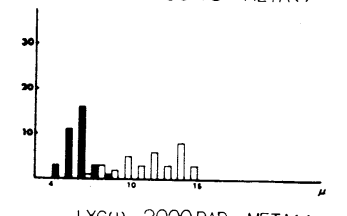

LYG(+) 2000RAD META(-)

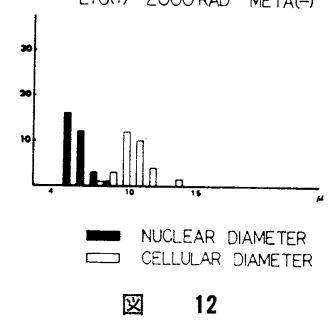

図 12
LYG(t) LI( $)$ META( -$)$
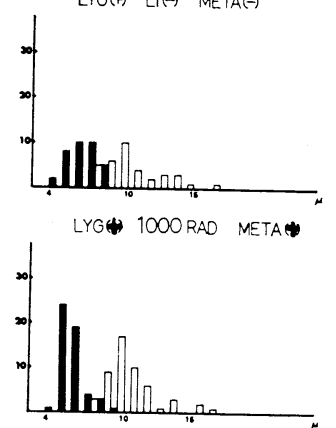

LYG(t) 2000 RAD META (t)

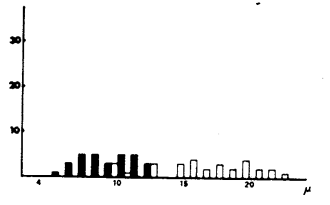

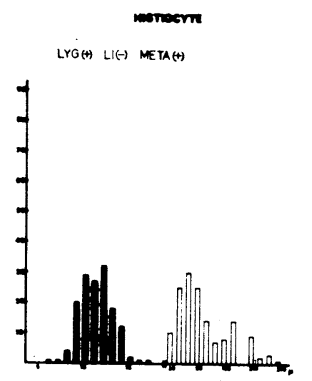

LYOH 1000RAD METAG

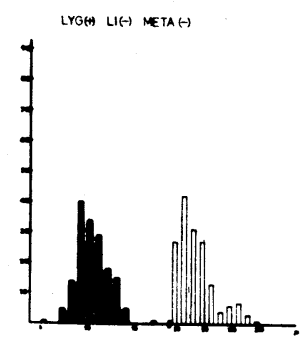

LYOS ZOOORAD METAG
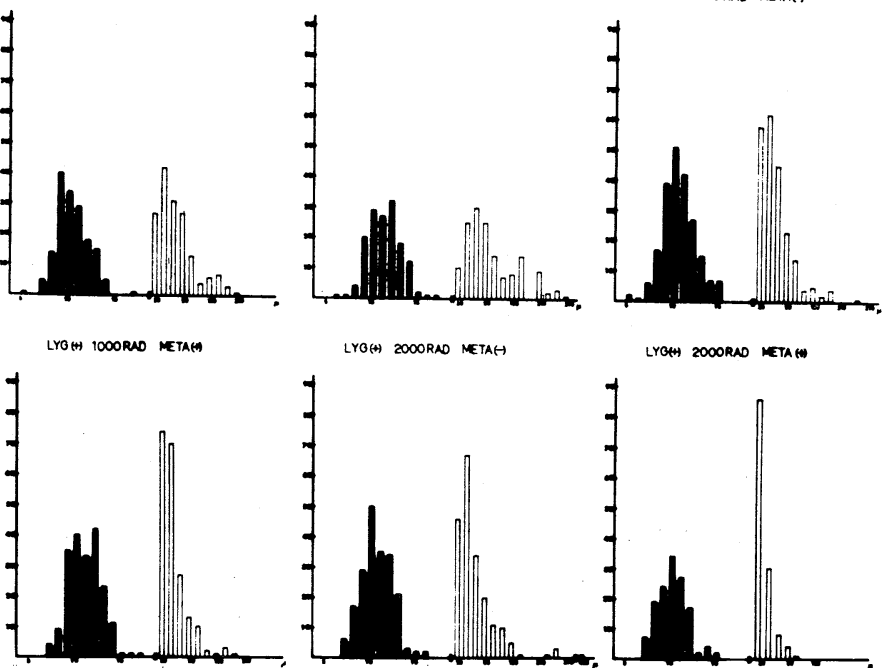

LYo : nperoceupar MU:LMAC: METASTASAS

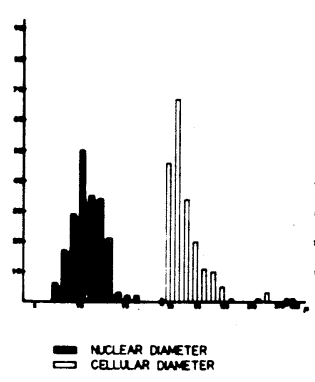

LYOW ZOOORND META WW

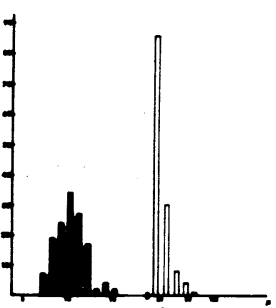

図

13 


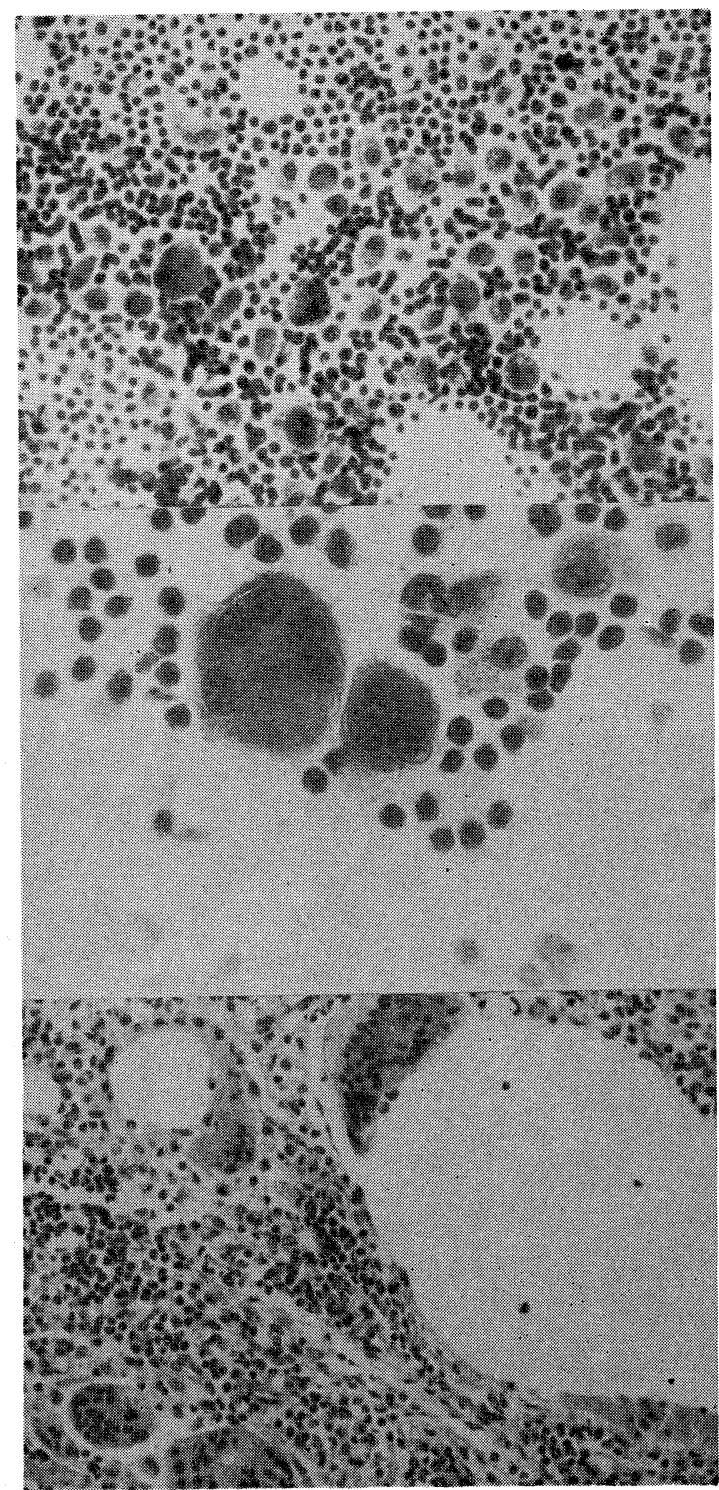

写真 1 リンパ節造影施行. 放射線非照射転移陰性. $\mathrm{a}$ : リンパ球の中に多核組織球と多数の細網細胞 をみた. b : 強拡大. $\mathrm{c}$ ：組織像.

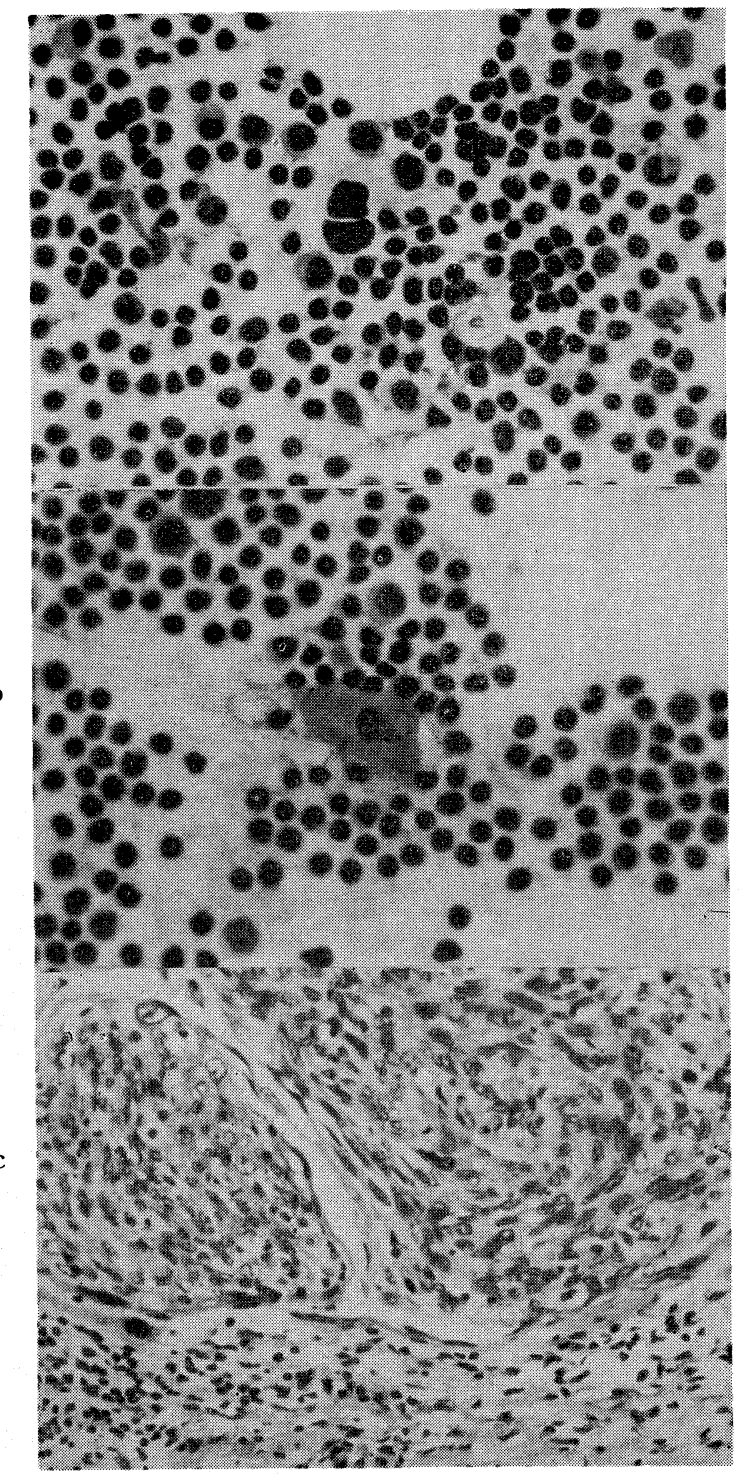

写真 2 リンパ節造影非施行. 放射線非照射転移陽性リン パ節.

a : リンパ球と数個の細網細胞，形質細胞に好ラ イトグリーン性癌細胞がみられる，b：好クレン 湆性癌細胞. c : 組織像. 


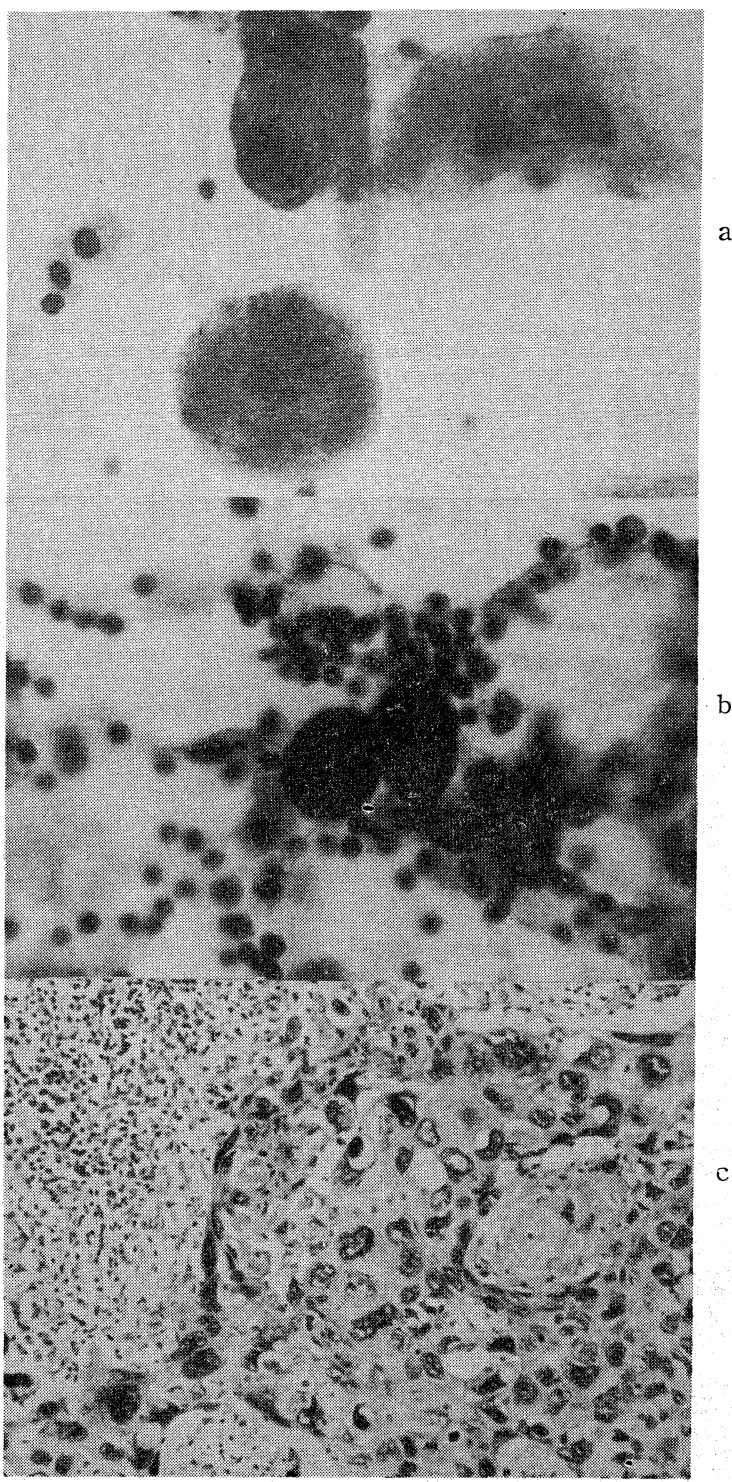

写真 3 リンパ節造影施行. $1000 \mathrm{rad}$ 照射転移陽性.

a : 放射線照射による癌細胞の変性像. b : 裸核.

c：組織像 